\title{
Meeting of the ACRL Committee to Revise the 1959 Standards
}

\section{for College Libraries}

The ACRL Committee to Revise the 1959 Standards for College Libraries met in Chicago on November 6, to continue its work toward the preparation of a national set of standards for college libraries. The committee discussed the correspondence it had received from the field and reviewed the status of recent state, regional, and foreign activities in the development and use of standards for academic libraries.

At the meeting, various members of the committee presented working papers for use in defining and categorizing those colleges for which the standards are to be used. David L. Perkins, head bibliographic librarian at California State University in Northridge, and James W. Pirie, librarian at Lewis and Clark College, are researching typologies currently used in analyzing colleges. Herman L. Totten, associate dean of the College of Library Science at the University of Kentucky, is attempting to identify and codify those library elements that should be in-

\section{ADDITIONAL ACRL NOMINATING COMMITTEES}

\section{ANTHROPOLOGY SECTION}

Marilyn L. Haas, Reference Librarian, Lockwood Memorial Library, State University of New York at Buffalo, Buffalo, NY 14214, Chairman

Two to be appointed.

\section{EDUCATION AND BEHAVIORAL SCIENCES SECTION}

Barbara S. Marks, Chief Reference Librarian, Bobst Library, New York University, 70 Washington Square South, New York, NY 10012, Chairman

Two to be appointed.

\section{UNIVERSITY LIBRARIES SECTION}

W. David Laird, University Librarian, University of Arizona, Tucson, AZ 85721, Chairman

Willis E. Bridegam, Director of Libraries, State University of New York at Binghamton, Vestal Parkway East, Binghamton, NY 13901

Anita R. Schiller, Reference Bibliographer, University of California, San Diego, La Jolla, CA 92037 cluded in the standards. Barbara G. LaMont, librarian at Vassar College, is preparing a projection of future trends for colleges. The committee agreed to release the papers at the Midwinter Meeting in January and to announce in February the availability of the papers for review and use by the membership. The committee continued its examination of whether or not a single set of standards can be applicable to the wide range of colleges and educational programs that exist today.

In its desire for comprehensive review and expression from the membership, the committee is scheduling a series of open hearings during the New York Conference in June. In addition, the committee requests information input and exchange from members, officers, and program chairmen of state and regional professional associations. Please contact the chairman of the committee, Johnnie E. Givens, librarian at Austin Peay State University in Clarksville, Tennessee.

\section{ADDITIONAL ACRL NOMINEES FOR OFFICES 1974/75}

\section{EDUCATION AND BEHAVIORAL SCIENCES SECTION}

\section{Vice-Chairman/Chairman-Elect}

Wayne Gossage, Director of Library Services, Bank Street College of Education, 610 West 112th St., New York, NY 10024

Emil Greenberg, Professor and Chief Librarian, Borough of Manhattan Community College, The City University of New York, 134 West 51st St., New York, NY 10020

\section{SLAVIC AND EAST EUROPEAN SECTION \\ Vice-Chairman/Chairman-Elect}

Andrew L. Makuch, Bibliographer for Collection Development, University of Arizona Library, Tucson, AZ 85721

Wasyl Veryha, Catalog Librarian, University of Toronto, Toronto, Ontario, Canada

Member-at-Large (one-year term)

Joseph Szeplaki, Head, Serials Department, Ohio University Library, Athens, OH 45701

Wojciech Zalewski, Curator, Russian and East European Materials, Stanford University Libraries, Stanford, CA 94305 